\title{
TRANSLATIO STUDIORUM \\ IN THE ACTIVITY OF THE INSTITUTE \\ FOR THE PRESERVATION OF MEDICAL TRADITIONS
}

\author{
Emanuela Appetiti \\ Institute for the Preservation of Medical Traditions \\ and Smithsonian Institution \\ appetitie@si.edu
}

If there is a salient characteristic of medieval knowledge and science more in particularly, it is translatio: during the Middle Ages, indeed, knowledge and science frequently moved, be it from one city to another, from one area to another, or from one polity to another. Without entering here into too much detail about this peregrinatio scientiae, it will suffice to mention the closure of the philosophical school of Athens in 519 by the Byzantine emperor Justinian (emp. 527-565), the translation movement of knowledge, science and also literature from Greek, Persian and Indian into Arabic in the Abbassid Empire from the late $8^{\text {th }}$ century on, the massive transfer of Arabic medicine to the West heralded by Constantine the African (d. after 1087 [?]) or, to mention just a few, the assimilation of Greek, viz. Aristotelian, philosophy by Wilhelm of Moerbeke (I215/35 - before I286) on the basis of Greek manuscripts copied by Ioannikios and, later on, the arrival of Greek scholars, scientists, book collectors and collections, and also copyists after the Fall of Constantinople on May 29, I453.

Twenty-first century scholarship also is living a significant translatio studiorum, but different in nature: not so much a geographical displacement — with all its components and consequences in polity, social structure and context, linguistics or cultural background-, but rather a transformation in the medium used to convey knowledge and science, which deeply transforms the approach to these disciplines. Such transformation goes well beyond a substitution of a medium with another as might have been the case when the support for book production shifted from papyrus to parchment and, later on, from parchment to paper. The digital medium, to name it, brings with it a totally new relation with the vehicle of knowledge and offers possibilities for the study of knowledge and science that were not only unavailable, but even unthinkable and unsuspected before its 
development. Capture of information, storage and exploitation, together with display are totally renewed.

This translatio studiorum of a new type-from one medium to another in which the new medium transforms the object of study and opens new fields of investigation-is the object of this presentation with a particular focus on Greek medical manuscripts and the work carried out in the Institute for the Preservation of Medical Traditions (henceforth the Institute). Taking advantage of the possibilities of this new medium, the Institute is laying down the basis for a renovated study of medieval manuscripts and Greek medical texts, which are both the codices and texts that transmitted the medicine of Classical Antiquity to subsequent periods until the Renaissance and the development of printing, and those in which physicians in the Byzantine Empire and beyond recorded the data of their personal experience of medicine.

The Institute for the Preservation of Medical Traditions is a research and education organization devoted to the study of the history of medicine and its tradition with a special focus on the Mediterranean area, the several populations who inhabited it, and their exchanges and interactions. Such general definition of its mission includes tasks like inventorying and cataloguing medical manuscripts and texts; digitizing and preserving the manuscripts; similarly, digitizing their texts and publishing them, and studying their contents in the most appropriate way, including by crossing the boundaries of traditional academic disciplines and bringing together medicine (among others, anatomy, physiology and pathology), therapeutics and pharmacy, and natural sciences (particularly botany, mineralogy and zoology for the materia medica). I will focus here on collecting primary information, organizing it in a meaningful way and making it available.

Collection of primary information consists in locating the manuscripts that have preserved the Greek medical treatises produced from Antiquity to the Renaissance. Although a list of manuscripts by authors and treatises has been compiled by a group of philologists coordinated by the German philologist Hermann Diels in the early $20^{\text {th }}$ century (Diels, 1905, 1906, and 1908, constituting what is traditionally called "the Diels"), no index of manuscripts was available. As early as 1985, Alain Touwaide generated such an index. In a pre-computer time, he did so by means of $12.5 \times 7.5 \mathrm{~cm}$ paper cards. Significantly enough, the late Dutch historian of medicine and Touwaide's colleague Joseph Sonderkamp did the same at the same time. The two connected but were not able to pursue a collaboration because of the premature death of Sonderkamp.

On the basis of Touwaide's paper card index, the Institute has created a computerized database that reproduces exactly the information provided in the Diels' catalogue. Such database is now available on the Internet $(<\mathrm{http}: / /$ medicaltradi- 
tions.org/collection/databases/greek>). Since information in the database exactly reproduces Diels' material, city and library names are in the form used in German, as are also authors' names (for example, Hippokrates and Galenos), except when German uses the Latin form of names. Titles of works, instead, are in Latin, in the standard form used in classical studies. For double-checking purposes, the database includes a reference to Diels' catalogue (volume and page). Similarly, it includes any note provided in the Diels for the sake of accuracy and completeness.

The database can be consulted by author's name, title of work, city or library. Whatever the search, data are displayed in alphabetical and/or numerical order. As an example, I cite the case of Alexander of Tralles (Table I). The works (including "Excerpta varia") are listed in alphabetical order, as are also the cities and libraries holding their manuscripts. The two manuscripts of the Epistula de lumbricis held by the Biblioteca Ambrosiana in Milano are listed according to the

\begin{tabular}{|c|c|c|c|c|c|c|c|c|c|c|c|}
\hline Author & Work & City & Library & \begin{tabular}{|l|} 
MS \\
Designation
\end{tabular} & Collection & Shelfmark & Year/Century & Folios & \begin{tabular}{|l|} 
Diels \\
Pages \\
\end{tabular} & Notes & View \\
\hline $\begin{array}{l}\text { Alexander } \\
\text { Trallianus } \\
\end{array}$ & $\begin{array}{l}\text { Epistula de } \\
\text { lumbricis }\end{array}$ & Escurial & Escurial & Scorial. & & $\begin{array}{l}\text { v. Puschm. I p. } \\
90 .\end{array}$ & & & $\begin{array}{l}\text { II, p. } \\
012 .\end{array}$ & Verbleib unbekannt & \begin{tabular}{|l|} 
View \\
Record
\end{tabular} \\
\hline $\begin{array}{l}\text { Alexander } \\
\text { Trallianus }\end{array}$ & \begin{tabular}{|l} 
Epistula de \\
lumbricis
\end{tabular} & Mailand & Bibl. Ambrosiana & Ambros. & & R 111 Sup. & XVI. & f. 264. & $\begin{array}{l}\text { N., p. } \\
045 .\end{array}$ & & $\begin{array}{l}\text { View } \\
\text { Record }\end{array}$ \\
\hline \begin{tabular}{|l|} 
Alexander \\
Trallianus \\
\end{tabular} & \begin{tabular}{|l} 
Epistula de \\
lumbricis
\end{tabular} & Mailand & Bibl. Ambrosiana & Ambros. & & S 3 Sup. & XVI. & f. 170. & $\begin{array}{l}\text { III, p. } \\
012 .\end{array}$ & & \begin{tabular}{|l|} 
View \\
Record
\end{tabular} \\
\hline \begin{tabular}{|l} 
Alexander \\
Trallianus \\
\end{tabular} & \begin{tabular}{|l}
$\begin{array}{l}\text { Epistula de } \\
\text { lumbricis }\end{array}$ \\
\end{tabular} & Oxford & Bibl. Bodleiana & & & $\begin{array}{l}\text { Puschm. I p. } \\
90\end{array}$ & & & $\begin{array}{l}\text { III, p. } \\
012 .\end{array}$ & & \begin{tabular}{|l|} 
View \\
Record
\end{tabular} \\
\hline $\begin{array}{l}\text { Alexander } \\
\text { Trallianus }\end{array}$ & Excerpta varia & Bologna & Bibl. Universitaria & Bonon. & & 3632 & $\mathrm{xv}$. & f. 207 & $\begin{array}{l}\text { III, p. } \\
013 .\end{array}$ & lera antidotos & \begin{tabular}{|l|} 
View \\
Record
\end{tabular} \\
\hline $\begin{array}{l}\text { Alexander } \\
\text { Trallianus }\end{array}$ & Excerpta varia & Escurial & Escurial & scorial. & & III. R. 3 & XI. & f. $141 \mathrm{v}$ & $\begin{array}{l}\text { II, p. } \\
013 .\end{array}$ & $\begin{array}{l}\text { Medicamina sine auctoris nomine; vgl. } \\
\text { Dioscuridis de mat. med. Libri V ed. M. } \\
\text { Wellmann, vol. II p. XII. Teilweise } \\
\text { Abscrhift in Wellmanns Besitz }\end{array}$ & $\begin{array}{l}\text { View } \\
\text { Record }\end{array}$ \\
\hline \begin{tabular}{|l|} 
Alexander \\
Trallianus \\
\end{tabular} & Excerpta varia & Escurial & Escurial & Scorial. & & 2. I. 8 & XIV. & $\begin{array}{l}\text { f. } 1.15 .20 .22 . \\
48 \mathrm{v}\end{array}$ & $\begin{array}{l}\text { III, p. } \\
013 .\end{array}$ & u. öfter. & \begin{tabular}{|l|} 
View \\
Record
\end{tabular} \\
\hline $\begin{array}{l}\text { Alexander } \\
\text { Trallianus } \\
\end{array}$ & Excerpta varia & Florenz & $\begin{array}{l}\text { Bibl. Mediceo } \\
\text { Laurentiana }\end{array}$ & Laurent. & App. & 2 & $\mathrm{xv}$. & $\begin{array}{l}\text { f. } 328 \text { v. } 332 . \\
338.345 \text { v. } 346\end{array}$ & $\begin{array}{l}\text { III, p. } \\
013 .\end{array}$ & & \begin{tabular}{|l|} 
View \\
Record
\end{tabular} \\
\hline $\begin{array}{l}\text { Alexander } \\
\text { Trallianus }\end{array}$ & Excerpta varia & Paris & Bibl. Nationale & Parisin. & & 2178 & XIV. & f. $11 \mathrm{v}$ & $\begin{array}{l}\text { III, p. } \\
013 .\end{array}$ & De febrium differentiis & $\begin{array}{l}\text { View } \\
\text { Record }\end{array}$ \\
\hline \begin{tabular}{|l|} 
Alexander \\
Trallianus \\
\end{tabular} & $\begin{array}{l}\text { Therapeutica. } \\
\text { Libri XII }\end{array}$ & Florenz & $\begin{array}{l}\text { Bibl. Mediceo } \\
\text { Laurentiana }\end{array}$ & Laurent. & plut. & 74,10 & XIV. & p. 86. & o11, p. & & \begin{tabular}{|l|} 
View \\
Record
\end{tabular} \\
\hline $\begin{array}{l}\text { Alexander } \\
\text { Trallianus }\end{array}$ & $\begin{array}{l}\text { Therapeutica. } \\
\text { Libri XII }\end{array}$ & Florenz & Bibl. Riccardiana & Riccard. & & 10 (K I 12) & a. 1583. & f. 67. & $\begin{array}{l}\text { II, p. } \\
011 .\end{array}$ & & \begin{tabular}{|l} 
View \\
Record
\end{tabular} \\
\hline
\end{tabular}

Table I. Greek Medical Manuscripts, Alexander Trallianus.

Online database of the Institute for the Preservation of Medical Traditions $<$ http://medicaltraditions.org/collection/databases/greek>. 
logical sequence of their respective shelfmarks (which, in this specific case, is alphabetical, but could be numerical in other libraries).

On the basis of his paper card index of the Diels, Touwaide systematically browsed the catalogue of the libraries all over the world from which collections of manuscripts were mentioned in the Diels, from large and well-known institutions to smaller and not-so-visible ones. This work of verification revealed that some of the catalogues used by Diels' collaborators were old and did not provide the shelfmark in use at the beginning of the $20^{\text {th }}$ century. Furthermore, in some collections, the shelfmark provided in the Diels are no longer in use. Finally, the two World Wars during the $2 \mathrm{O}^{\text {th }}$ century provoked losses and changes in manuscript collections, as did also the changing fate of collections. Although collaboration with local curators was of fundamental importance, personal examination of manuscripts and collections was indispensable. Touwaide embarked in decades of travels to personally examine many collections of Greek manuscripts, be it in major repositories as the British Library in London, the Bibliothèque nationale de France in Paris and the Biblioteca Apostolica Vaticana in Vatican City or others, important or secondary and not necessarily easy to access as St. John's Monastery in the island of Patmos, the Monê Leimônos in the island of Lesbos and many others. He could personally browse entire collections, inspect hundreds of codices, catalogued or not, and analyze their contents to possibly detect texts that escaped the attention of previous cataloguers, historians of medicine or historians of texts (Touwaide, I99I and 1992).

While still checking Diels' information and traveling worldwide, Touwaide went beyond and consulted available printed catalogues of Greek manuscripts, all the more because, during the second half of the $20^{\text {th }}$ century, codicology went through an unprecedented development that generated many new catalogues of Greek manuscripts. All such works, be they new or earlier ones, have been systematically listed from 1948 on in the several editions of the Répertoire des bibliothèques et des catalogues de manuscrits grecs compiled by the late Marcel Richard (1907-1976) (Richard 1948 and 1958 , with the $3^{\text {rd }}$ edition by Olivier, 1995. A $4^{\text {th }}$ edition is in preparation).

The recent increase in speed of communication (the email) and easy access to information about libraries, collections and curators (the Websites of the libraries) allowed for more direct contacts with the libraries which resulted in accelerated verification of information and increased efficiency.

The search for Greek medical manuscripts, which sometimes became an investigation in the way of Hercule Poirot, brought to light over 2,300 different codices with medical content. This number is significant as the paper card index of Diels' catalogue made it possible to determine that the Diels contains ca. I,750 
different items. Touwaide's work of verification revealed that over 250 of these items are erroneous, be it because they are duplicates, or mistakes, or Latin manuscripts, for example. Considering an actual number of ca. I,500 Greek items, the total of 2,300 reached by Touwaide represents an increase of 50\% (Touwaide, 2008 and 2009).

Building on Touwaide's personal work and the database developed by the Institute, scholars in the Institute work on digitizing relevant manuscripts and uploading images on the Internet. This phase proceeds in different ways, depending on the policy of the libraries. There are almost as many cases as libraries: some have digitized their manuscripts and provide their images for free or against payment; some have digitized their manuscripts and have uploaded the images on the Internet; some others do not embark in such program; and some others are interested in having their manuscripts digitized, but do not have yet digital images and let the Institute's scholars digitize their codices.

Whatever the source, when the Institute has digital images, it uploads them on its Website. Images can be accessed according to two different, yet complementary parameters: by page or by text (for a sample, see <http://medicaltraditions.org/padova> for the manuscript 194 in the Biblioteca del Seminario Vescovile in Padova [Padua], Italy) (Fig. I). By page, users visualize first thumbnail images of the whole manuscript (Fig. 2) and can click on any of them to obtain a larger, full-screen image. From such starting point they can flip through the whole manuscript as if they were browsing it. By text, users visualize the list of the major textual units of the text in the manuscript they are interested in and can click on any such unit (Fig. 3). They obtain an image of the page in the manuscript that contains such textual unit, together with a transcription (in machine-readable format) of the text on this page (Fig. 4). When, instead, the Institute does not receive or acquire digital images of manuscripts, but can access such images through the Internet (from the Website of the libraries that own the manuscripts), it creates a link to these images in order to give a direct access to them. In this case, while browsing manuscripts page by page may not be possible, reading their texts by segments is still possible, however.

In order to make digital consultation of manuscripts (be it by page or by text) as informative as possible, images in the Website of the Institute are introduced by a thorough codicological and paleographical description of the manuscripts resulting from a personal autopsy. Such description is complemented with a detailed list of the texts contained in the codices (which includes references to the exact folios and available editions) and a bibliographical list.

Digitization of texts is not limited to the manuscripts reproduced in the Institute's Website, but includes a large collection of medical treatises. It is the 
Institute's objective, indeed, to develop a comprehensive digital library of Greek medicine, be it classical, Byzantine, Renaissance or posterior. To this end, the Institute has created appropriate Websites, each of which is devoted to a specific period or a major component in the history of Greek medicine as collection of writings attributed to Hippocrates, that is, the Corpus Hippocraticum (<http:// DigitalHippocrates.org $>$ ), Greek medicine during the Classical period ( $<\mathrm{http}: / /$ GreekMed.org $>$ ) and Greek medicine during the Byzantine period (332 to I453) $(<\mathrm{http}: / /$ ByzantineMedicine.org $>)$. In the future a Website will be created for the Greek medical texts of the post-byzantine period (<http://iatrosophia.org $>$ ).

This collection of texts from manuscripts is completed by another collection of material, that is, the printed versions of Greek medical texts. Many such editions have been digitized in libraries and/or institutions all over the world, principally the Bibliothque Interuniversitaire Santé in Paris and the Corpus Medicorum Graecorum at the Academy of Sciences in Berlin. Whereas the Websites of these organizations offer the whole volumes digitized en bloc and users need to flip through them to find a specific text, the Institute segments the volumes by texts and offers a link to each and every of their texts, so that consulting such volumes is made much more direct and easier. These links to digital versions of printed editions can be found in the three Websites of the Institute above.

Complementarily, scholars at the Institute have created and continue to develop a Website devoted to the illustrated herbals printed between I487 to I65I. The purpose and function of this site is the same as for manuscripts. It is a digital library of all printed production on this matter, that can be accessed by author, title, date/period and by plant (<http://www.sil.si.edu/digitalcollections/herbals>; Touwaide, 2007).

The Institute's long-term objective is to link the Websites on printed herbals and on Greek manuscripts in order to make it possible to follow all the itinerary of knowledge from Antiquity to the dawn of modern science, through its several phases, areas, and cultures within the Mediterranean and even beyond, up to China. A recent study made at the Institute on the basis of such massive quantity of material has shown indeed that the two worlds were connected as early as the Hippocratic period (Touwaide and Appetiti, 2013).

Translatio studiorum has now a different meaning, no longer limited to the geographical move of a body of knowledge, but to its transfer from the visual space of the page to the invisible depth of the digital world with all its potentialities which will reveal aspects of ancient and medieval knowledge that had remained unsuspected so far. 


\section{BIBLIOGRAPHY}

Diels, H., 1906: Die Handschriften der antiken Ärzte. I. Teil. Hippokrates und Galenos, Berlin.

-, 1907: Die Handschriften der antiken Ärzte. II. Teil. Die übrigen Ärzte ausser Hippokrates und Galenos, Berlin.

- - 1908: Bericht über den Stand des interakademischen Corpus Medicorum Antiquorum und erster Nachtrag zu den in den Abhandlungen I9os und 1906 veröffentlichten Katalogen: Die Handschriften der antiken Ärzte. I. und II. Teil. Berlin.

Olivier, J.-M., I995: Répertoire des bibliothèques et des catalogues de manuscripts grecs, troisième édition entièrement refondue, Turnhout.

Richard, M., 1948: Répertoire des bibliothèques et des catalogues de manuscripts grecs, Paris.

— I958: Répertoire des bibliothèques et des catalogues de manuscripts grecs, deuxième édition, Paris.

Touwaide, A., I99I: "The Corpus of Greek Medical Manuscripts: A Computerized Inventory and Catalogue", Primary Sources and Original Works, I, pp. $75-92$.

— I992: "Pour un Corpus des manuscrits médicaux gecs", in A. Garzya (ed.), Tradizione e ecdotica dei testi medici tardo-antichi e bizantini. Atti del Convegno internazionale, Anacapri, 29-3I ottobre 1990, Naples, pp. 356-366.

_ _, 2007: "Lillustrazione botanica negli erbari a stampa del XV e XVI secolo: il programma di ricerca PLANT e il suo contributo all'analisi delle rappresentazioni di piante, in M. Breccia Fratadocchi and S. Buttò (eds.), I laboratori della salute, Sansepolcro, pp. III-II6.

—, 2008: "Greek Medical Manuscripts. Toward a New Catalogue", Byzantinische Zeitschrift, IOI, pp. 199-208.

—, 2009: "Byzantine Medical Manuscripts: Towards a New Catalogue with a Specimen for an Annotated Checklist of Manuscripts Based on an Index of Diels' Catalogue", Byzantion, 79, pp. 453-595.

Touwaide, A., and Appetiti, E., 2013: "Knowledge of Eastern materia medica (Indian and Chinese) in pre-modern Mediterranean medical traditions: A study in comparative historical ethnopharmacology", Journal of Ethnopharmacology, I48, pp. 36I-378. 


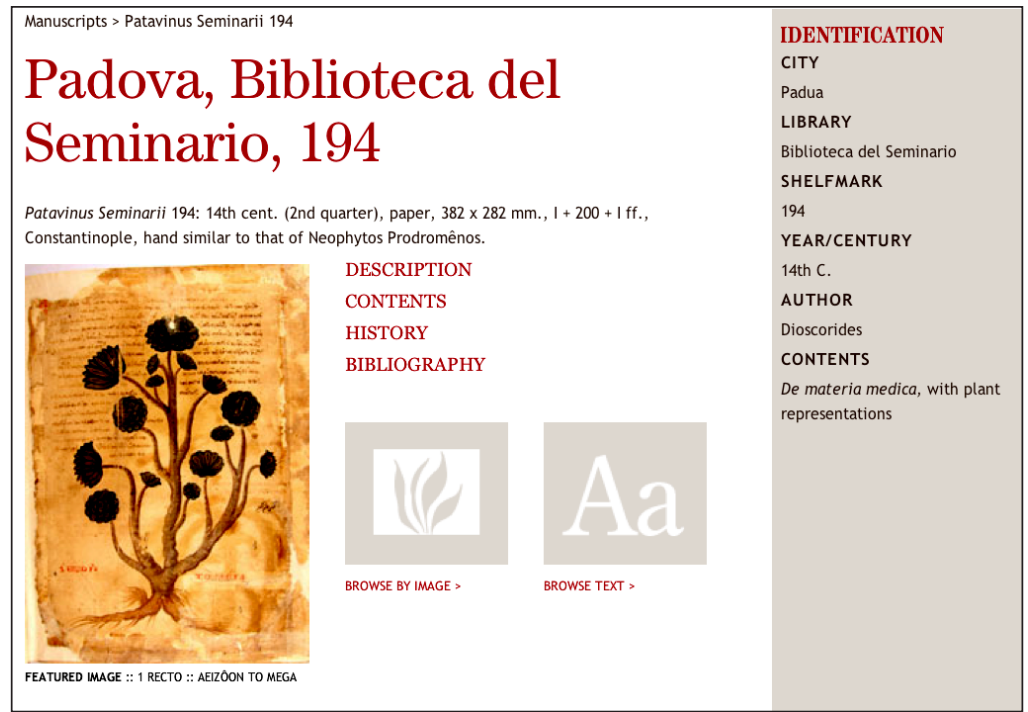

Fig. I. Digitization of manuscript Padova, Biblioteca del Seminario, I94. From the Website of the Institute for the Preservation of Medical Traditions <http://medicaltraditions.org/padova $>$.

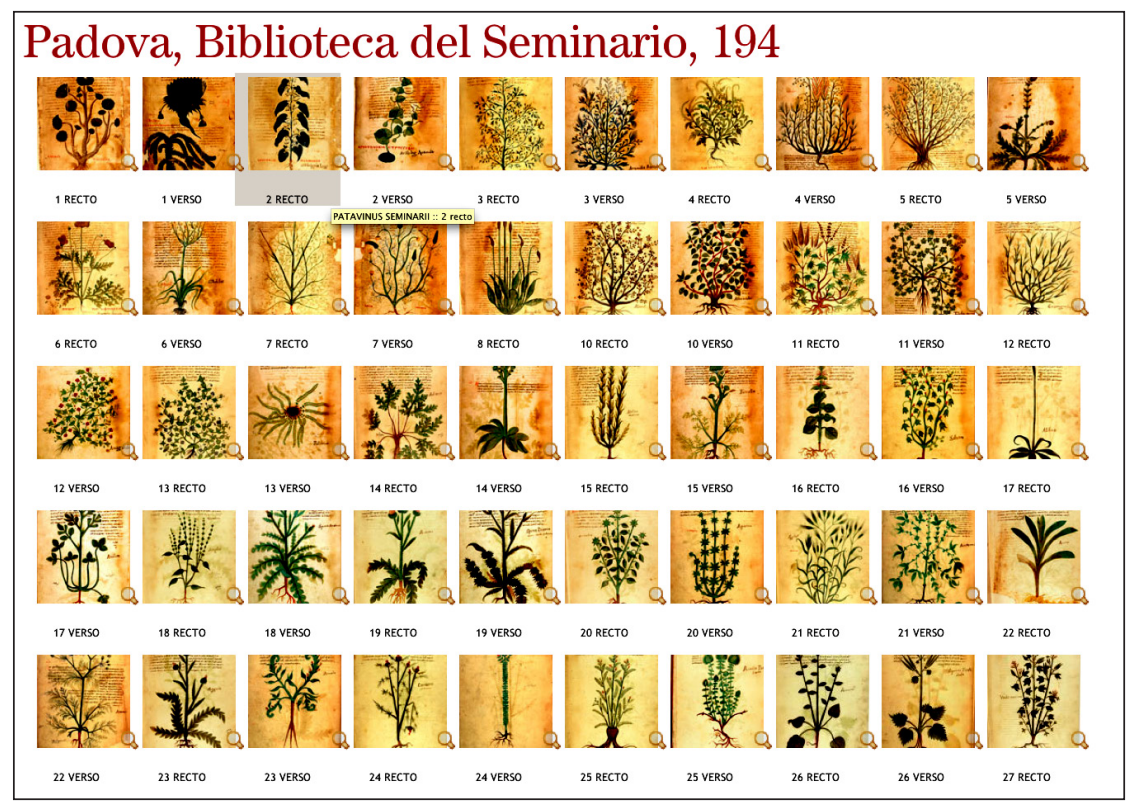

Fig. 2. Digitization of manuscript Padova, Biblioteca del Seminario, 194, by pages.

From the Website of the Institute for the Preservation of Medical Traditions $<$ http://medicaltraditions.org/padova/images $>$. 


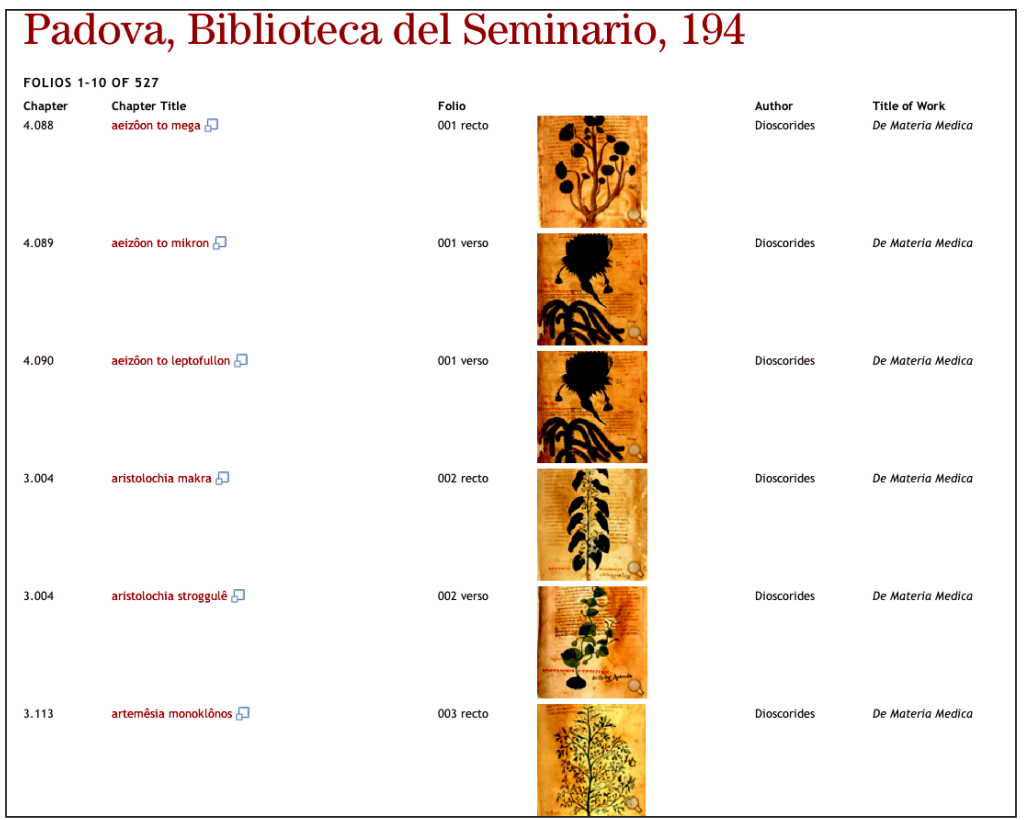

Fig. 3. Digitization of manuscript Padova, Biblioteca del Seminario, 194, by texts.

From the Website of the Institute for the Preservation of Medical Traditions $<$ http://medicaltraditions.org/padova/text $>$.

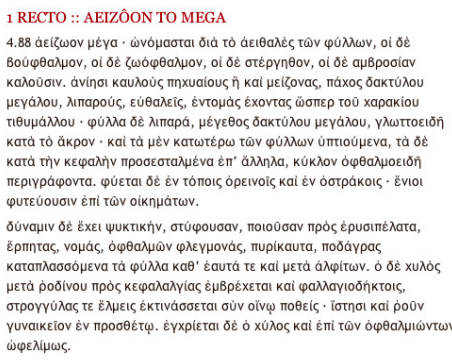

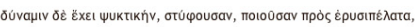

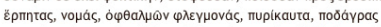

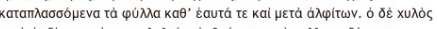

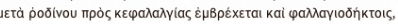

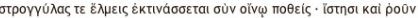

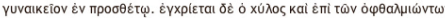

$\dot{\omega} \varphi \varepsilon \lambda i \mu \omega \varsigma$.

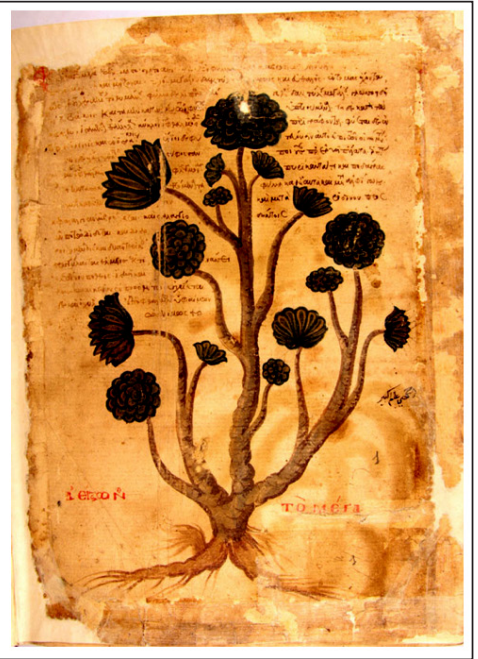

Fig. 4. Digitization of manuscript Padova, Biblioteca del Seminario, I94,

a page and its text in machine-readable format.

From the Website of the Institute for the Preservation of Medical Traditions $<$ http://medicaltraditions.org/padova/text $>$. 
